University of Nebraska - Lincoln

DigitalCommons@University of Nebraska - Lincoln

US Army Research

U.S. Department of Defense

2001

\title{
Child Emotional Maltreatment: A 2-year Study of US Army Cases
}

\author{
Linda K. Jellen \\ Social Work Service, Tripler Army Medical Center, 1 Jarrett White Road, Honolulu, HI 96859, USA \\ James E. McCarroll \\ Department of Psychiatry, Uniformed Services University of the Health Sciences, Bethesda, MD, USA \\ Laurie E. Thayer \\ Department of Psychiatry, Uniformed Services University of the Health Sciences, Bethesda, MD, USA
}

Follow this and additional works at: https://digitalcommons.unl.edu/usarmyresearch

Part of the Operations Research, Systems Engineering and Industrial Engineering Commons

Jellen, Linda K.; McCarroll, James E.; and Thayer, Laurie E., "Child Emotional Maltreatment: A 2-year Study of US Army Cases" (2001). US Army Research. 26.

https://digitalcommons.unl.edu/usarmyresearch/26

This Article is brought to you for free and open access by the U.S. Department of Defense at DigitalCommons@University of Nebraska - Lincoln. It has been accepted for inclusion in US Army Research by an authorized administrator of DigitalCommons@University of Nebraska - Lincoln. 


\title{
Child emotional maltreatment: a 2-year study of US
} Army cases 论, 动抎

\author{
Linda K. Jellen ${ }^{\mathrm{a}, *}$, James E. McCarroll ${ }^{\mathrm{b}}$, Laurie E. Thayer ${ }^{\mathrm{b}}$ \\ ${ }^{a}$ Social Work Service, Tripler Army Medical Center, 1 Jarrett White Road, Honolulu, HI 96859, USA \\ ${ }^{\mathrm{b}}$ Department of Psychiatry, Uniformed Services University of the Health Sciences, Bethesda, MD, USA
}

Received 21 April 2000; received in revised form 6 September 2000; accepted 15 September 2000

\begin{abstract}
Objective: Reports of childhood emotional maltreatment have increased greatly over the past decade. The objective of this research was to determine the types of emotional maltreatment substantiated in a community of US Army families residing temporarily in Germany. Such a description may help to improve the understanding of how a jurisdictional body defines emotional maltreatment in day-to-day practice.
\end{abstract}

Method: Data were obtained from a review of the minutes of case review committees (CRCs) for 181 cases of child emotional abuse in 1997-1998. We determined the type, number, and severity of incidents, the substantiation rate, and the situations to which children were exposed.

Results: The most frequently substantiated type of incident was witnessing domestic violence, $60 \%$ of all cases. Primary emotional abuse was found in $26 \%$ of cases, while emotional abuse in conjunction with child physical abuse or child neglect was found in $14 \%$ of cases. The more severe the case, the more likely it was to be substantiated.

Conclusions: Emotional maltreatment was substantiated more as a single type than in combination with other forms of maltreatment. Seeing emotional abuse as a single entity may allow clinicians to focus on a relationship or situation (such as spouse abuse) that is potentially harmful to a child. However, recognizing the emotionally abusive aspects of child physical abuse and neglect could allow an expanded treatment plan that could include treatment of the emotionally abusive behavior to

is The opinions expressed by the authors are not necessarily those of the Department of the Army or the Department of Defense.

败 At the time the initial data was collected, the first author was Social Work Consultant, US Army Europe Region Medical Command, Heidelberg, Germany.

* Corresponding author. 
strengthen the relationship of the caregiver to the child, in addition to the focus on the physical abuse and neglect. @ 2001 Elsevier Science Ltd. All rights reserved.

Keywords: Child abuse; Emotional abuse; Military; Epidemiology; Spouse abuse

\section{Introduction}

Psychological maltreatment has been called the core issue in child abuse and neglect (Garbarino, Guttmann, \& Seeley, 1986; Garbarino \& Vondra, 1987; Hart, Germain, \& Brassard 1987; Navarre, 1987; Hart, Binggeli, \& Brassard, 1998), characterized as unifying the dynamics that underlie all forms of child abuse and neglect (Hart \& Brassard, 1987). It has been suggested that psychological maltreatment is more closely tied to negative outcomes than is physical abuse (Crittenden, Claussen, \& Sugarman, 1994). Psychological maltreatment has serious consequences for children, but the reasons for its negative consequences are not well understood (Claussen \& Crittenden, 1991). Given that this form of child abuse is not new (Garrison, 1987; Thompson \& Kaplan, 1996), surprisingly little has been published on the topic. Among the difficulties in studying it have been shifts of interest in various forms of child maltreatment (e.g., physical abuse, sexual abuse), lack of integration of research findings across areas (compartmentalization), and isolation from theory (Rosenberg, 1987). Other barriers have been the lack of definitions and standards (particularly in the absence of observable physical injury), the reluctance of the judicial system to become involved in families, and the increasing overlap and politicization of this form of child abuse with the abuse of women.

\section{Definitions, measures, and theory}

Garbarino, Guttmann, and Seeley (1986) considered psychological maltreatment to be an attack by an adult on a child's development of self and social competence in a pattern of behavior that could take five forms: rejecting, isolating, terrorizing, ignoring, and corrupting. They believed that the term psychological maltreatment was preferable to emotional abuse because it subsumes both affective and cognitive aspects of child maltreatment. (We found little consistency in the literature between the use of the term psychological abuse and emotional abuse. We prefer to use the term emotional abuse in this paper since this is the term the US Army uses for its cases of emotional maltreatment.)

Hart, Germain, and Brassard (1987), and Hart and Brassard (1987) recommended the development of operational definitions of psychological maltreatment embodying unambiguous and tested standards. They suggested operationally defining psychological maltreatment by caregivers as spurning (rejecting and hostile degradation), terrorizing, isolating, exploiting or corrupting acts, and denying emotional responsiveness (Hart \& Brassard, 1991). Other definitions have emphasized the consequences for the child rather than the behavior of the caregiver (Somer \& Braunstein, 1999). These include acts that threaten the development of a positive self-concept (Garbarino, Guttman, \& Seeley, 1986), basic psychological needs 
(Hart \& Brassard, 1987), or parental behavior that jeopardizes the well-being, normal functioning, and developmental potential of the child (Navarre, 1987).

Emotional abuse can refer to a relationship rather than to a series of events (Glaser \& Prior, 1997), or it can be confined to parental acts that are purely psychological in nature (McGee \& Wolfe, 1991). Hart and Brassard (1991) believed that the parental behavior should not be called maltreatment unless such behavior has been established to produce a negative impact on child development. This statement then includes consideration of the threat of harm as well as extant harm to a particular child. The implication of this approach is to measure both, but that may not always be feasible, particularly in the case of young children. The guidelines of the American Professional Society on the Abuse of Children (APSAC) accept the concept of psychological maltreatment to mean a repeated pattern of caregiver behavior in which the message is conveyed to children that they are worthless, flawed, unloved, unwanted, endangered, or only of value in meeting another's needs (APSAC, 1995).

Emotional abuse is difficult to identify by psychiatric assessment because there is no consensus as to what constitutes emotional abuse, victims are unlikely to complain of it, symptoms are nonspecific, and there are no pathognomonic findings on examination (Thompson \& Kaplan, 1996).

Gough (1996) discussed definitions of child abuse including the positive and negative aspects of specific and operational definitions. The basic elements of all definitions of abuse are harm or threat of harm and responsibility for that harm, and a unifying theoretical framework to establish definitions and concepts of child abuse. Without clear standards for emotional abuse, it may be difficult to convince workers and parents that it is present. Physical acts or omission of acts by parents and caretakers are easier to introduce into evidence than the more subtle types of maltreatment that occur in emotional abuse.

There have been attempts to develop measurement instruments for childhood emotional abuse such as the Psychological Maltreatment Rating Scales for assessing the videotaped interactions of high-risk child-mother dyads (Brassard, Hart, \& Hardy, 1993). It was found to have two factors of positive parenting and one of emotional abuse. Sanders and BeckerLausen (1995) developed the Child Abuse and Trauma Scale (CATS), an index of the frequency and type of negative experiences of children and adolescents including sexual abuse, punishment, a negative home environment, and neglect. Kent and Waller (1998) attempted to extend the CATS to include an emotional abuse subscale by adding seven items of parents' behavior toward children based on face validity: ridicule, insult, dislike, get really mad, verbally lash out, yell, and blame the child for things he or she did not do.

Much of the research on children who witness domestic violence had been based on social learning and learned helplessness models (Kolbo, Blakely, \& Engleman, 1996), family systems theory, trauma theory, or interpersonal explanations (Graham-Bermann \& Hughes, 1998). Hart, Binggeli, and Brassand (1998) reviewed a basic human needs model, derived from the work of Maslow (1970), of psychological maltreatment as one that had particularly strong explanatory and heuristic support. This model postulates that psychological maltreatment thwarts or is a direct attack on the fulfillment of basic human physiological, safety, love, belonging, and esteem needs. While theory and definitions support the identification of psychological maltreatment, its nature and significance depends on its impact on child victims (Hart, Binggeli, \& Brassand, 1998). 


\section{Effects of child emotional abuse}

Psychological maltreatment has serious implications for child and adult mental health as they related to current psychosocial functioning. It was uniquely associated with low self-esteem in a study of university women's retrospective reports of childhood abuse (Briere \& Runtz, 1990). In a study of 260 persons identified as physically abused, psychologically abused, or non-abused based on responses to a child abuse questionnaire, psychological abuse predicted levels of depression, self-esteem, and attributional style when physical abuse effects were controlled (Gross \& Keller, 1992). In a community sample of women with a history of physical, emotional, and sexual abuse in childhood there were associations between abuse and a range of mental health, interpersonal, and sexual problems in adult life (Mullen, Martin, Anderson, Romans, \& Herbison, 1996). Hart, Binggeli, and Brassand (1998) summarized reports of the impact of psychological maltreatment from the American Humane Association (Wald, 1961), the National Center on Child Abuse and Neglect (Broadhurst, 1984), and Hart, Germain, and Brassard (1987). As psychological maltreatment is considered to be the core component in child abuse and neglect, the impact of such maltreatment on children is broad and profound. The effects are subsumed under the categories of (1) an inability to learn, (2) an inability to build or maintain satisfactory interpersonal relationships, (3) inappropriate behavior and feelings under normal circumstances, (4) a pervasive mood of unhappiness or depression, and (5) a tendency to develop physical symptoms.

\section{Effects of witnessing spousal violence}

The witnessing of spousal violence by children has received much recent attention. Marital conflict is related to numerous indexes of child maladjustment, although the process by which this might occur is largely unexplored (Grych \& Fincham, 1990). Exposure to more frequent episodes of interparental conflict leads to greater distress and more behavior problems in children. Exposure to more intense marital conflict (including physical aggression) is also related to child problems and is more upsetting than less severe conflict, and children as young as 2 years old may be sensitive to the content of conflict. A review of 34 studies of children who witnessed mother assault found that such children are an at-risk population for varying forms of post-traumatic stress disorder (Lehmann, 2000). In the studies reviewed, children were exposed to events that involved threatened or actual death, or serious injury. All the children experienced fear, horror, and a sense of helplessness. The categories of traumatic response found were: intrusive re-experiencing of the event, repetitive play, physiological reactivity, sleep problems, trauma-specific fears, memory distortions, withdrawal and regression, sense of a foreshortened future, school-related difficulties, irritability and anger, and associated emotional responses.

School-age boys who witnessed parental violence were compared to those who had been abused themselves and to a control group with no family violence (Jaffe, Wolfe, Wilson, \& Zak, 1986). Witnesses and abused boys were significantly higher than controls on both internalizing and externalizing measures. Boys exposed to family violence had adjustment difficulties similar to those of abused boys and differed significantly from control boys. 
Hughes (1988) compared abused and non-abused child witnesses to parental violence who were temporarily living in a shelter for abused women to comparison children from a similar economic background. There was more distress observed in the abused-witness children than in the comparison group, and the non-abused witnesses were somewhat between the abused and comparison group on distress measures. Exposure to family violence was correlated with vulnerability, and resilience and protective factors in a clinical sample of 60 children, ages 8-11 years (Kolbo, 1996). Exposure was related to self-worth among boys and to behavior problems among girls. High levels of support protected only boys from lower self-worth as an effect of exposure to family violence.

Children who witness domestic violence are at risk for maladaptation in behavioral, emotional, social, cognitive, and physical functioning, although not all these possible outcomes topics had equally strong evidence of an effect (Kolbo, Blakely, \& Engleman, 1996). The evidence for a relationship between witnessing domestic violence and its effects on children was equivocal for children's behavior and their social and physical functioning, but there did seem to be an effect on emotional and cognitive development. Fantuzzo, Boruch, Beriama, Atkins, and Marcus (1997) estimated the prevalence of children's exposure to assault of females in five major US cities. Young children were disproportionately present in households with domestic violence. These children were also exposed to excessive levels of additional developmental risk factors and were involved in the incidents to varying degrees. O'Keefe (1998) found that a high percentage of adolescents in her sample who had witnessed high levels of interparental violence also inflicted a high level of dating violence. In another study, $14 \%$ of undergraduate students reported witnessing at least one episode of physical interparental conflict as children. They also reported higher levels of current psychological distress than a comparison group who had never witnessed any interparental physical violence. These findings occurred after controlling for divorce, parental SES, physical abuse of the child, parental alcoholism, and nonphysical discord between the parents (Henning, Leitenberg, Coffey, Bennett, \& Jankowski, 1997).

In an 18 year longitudinal study of a birth cohort of New Zealand children, those who reported high levels of exposure to interparental violence had elevated rates of adjustment problems at age 18 such as mental health problems, substance abuse, and criminal offending (Fergusson \& Horwood, 1998). Much of the risk for later problems in children seemed to arise from the social context (family socio-economic background, parental change, parental adjustment, childhood disadvantage, and exposure to child abuse) in which interparental violence occurs. Nevertheless, exposure to father-initiated violence was associated with increased risks of anxiety, conduct disorder, and property crime, while exposure to mother-initiated violence was associated with increased risks of later alcohol abuse and dependence.

\section{Epidemiology}

There have been two sources of data on child emotional abuse: population prevalence studies and case reports (treated prevalence). The three national incidence studies of child abuse and neglect are the major sources of population prevalence figures. The first national incidence study (NIS-1) was published in 1981 (US Department of Health and Human 
Services, 1981), the second (NIS-2) in 1988 (US Department of Health and Human Services, 1988), and the third (NIS-3) in 1996 (Sedlak \& Broadhurst, 1996). The NIS-3 was a nationally representative sample of the prevalence of child maltreatment by a parent or caretaker. Two types of emotional maltreatment of children were reported: emotional abuse and emotional neglect. The NIS-3 estimated the number of cases of children thought to be abused or neglected by using reports from community sentinels from child protective services, schools, and law enforcement agencies who would be expected to see such cases. Emotional abuse was categorized as close confinement (such as tortuous restriction of movement or confining a child to an enclosed area), verbal or emotional assault, and other or unknown abuse. The components of emotional neglect were: inadequate nurturance/ affection, chronic/extreme spouse abuse, permitted drug/alcohol abuse, permitted other maladaptive behavior, refusal of psychological care, delay/failure of psychological care, and other inattention to emotional needs. Two sets of definitional standards were used concerning harm and perpetrator characteristics: a harm standard and an endangerment standard. Under the harm standard, a child must have suffered demonstrable harm as a result of the maltreatment. The endangerment standard included all the harm standard children, but added those children who had not yet been harmed by maltreatment, but who experienced abuse or neglect that put them in danger of being harmed (Sedlak \& Broadhurst, 1996).

Rates per thousand children of emotional abuse increased from 2.1/1,000 in the NIS-1 to $2.5 / 1,000$ in the NIS-2, to 3.0/1,000 in the NIS-3. For emotional neglect, the increase was from 0.9/1.000 (NIS-1) to 3.2/1,000 (NIS-3) (Kaplan, Pelcovitz, \& Labruna, 1999). Sedlak and Broadhurst (1996) reported a 333\% increase for emotional neglect defined by a harm standard compared to the NIS-2. Under an endangerment standard, there was a $183 \%$ increase in emotional abuse, and $188 \%$ increase in emotionally neglected children.

There are many types of case report data on child emotional abuse, but they are difficult to compare. The US Department of Health and Human Services publishes yearly reports on child maltreatment from the states on cases that are reported to the National Child Abuse and Neglect Data System (US Department of Health and Human Services, 1999) which uses 1997 data. The 1997 report indicated that the number of victims of psychological abuse or neglect had slightly decreased from 1990 (6.5\%) to 1997 (6.1\%). However, Kaplan, Pelcovitz, and Labruna (1999) noted that these are probably underestimates due to the primary emphasis of these agencies on the physical safety of children. Rates of emotional abuse are rising annually in the United Kingdom, 13\% of all registrations in 1995 and 15\% in 1996 (Glaser \& Prior, 1997). When emotional abuse was counted equally with other categories of child abuse, the rate of registration was 24\% in 1996.

Another source of case data is the US Army (Army Regulation 608-18, 1995). Emotional maltreatment is one of five categories of child maltreatment recognized by the US Army Family Advocacy Program (FAP) and recorded in the Army Central Registry (ACR). The Army has seen a three-fold increase in the number of substantiated cases of emotional abuse (from $8.5 \%$ to $19 \%$ ), and an increase in rates/1,000 from 0.59 to 1.26 from 1988-1997 (McCarroll, Thayer, Newby, Ursano, Norwood, \& Fullerton, 1999). Emotional abuse is defined as "a pattern of active, intentional berating, disparaging, or other abusive behavior toward the victim that may not cause observable injury. Emotional neglect involves passive or passive-aggressive inattention to the victim's psychological needs, nurturing, or psycho- 
logical well-being" (AR 608-18, 1995). We feel confident that most instances of emotional neglect would be classified as emotional maltreatment rather than neglect under the Army's nomenclature. Neglect is well defined in AR 608-18 as instances of physical neglect including inadequate supervision, inattention to the child's physical needs, and other examples of observable physical neglect.

Incidents of abuse may come to the attention of the FAP from a variety of military and civil sources including law enforcement, medical and dental services, command authorities, and other military and civil agencies. Cases can be investigated by a variety of military agencies including law enforcement officials, social workers, commanders, and other individuals in the military community with responsibilities for family and soldier welfare. In order to be entered into the ACR, cases must be reviewed and determined as substantiated or unsubstantiated by a multidisciplinary case review committee at the medical treatment facility of each major Army installation. Cases are substantiated based on a preponderance of available information that indicates that maltreatment occurred. Case substantiation is a clinical decision, the result of which is a treatment plan formulated for each case by the multidisciplinary CRC. The Army may be in a more unique position to identify child emotional maltreatment than civilian communities because the same committee generally reviews the reported cases of child and spousal abuse.

\section{Methods}

The purpose of this research was to determine the number and type of incidents that were evaluated in a sample of US Army communities. We examined the substantiation rate, the situations to which children were exposed that were called emotionally abusive, whether it was noted in the case review minutes if an assessment had been performed on the child, and the recommended interventions.

\section{Population}

The population consisted of soldiers and their family members assigned to US Army installations in Germany. Soldiers with families are generally assigned to Germany for a period of 3 years. About $85 \%$ of married soldiers live on US Army installations in Germany; the remainder lives on the local economy near the installation to which the soldier is assigned. While there are additional stresses of living overseas, a variety of military social and medical services are generally available to this population. This community has certain research advantages over a United States population because all the cases of maltreatment are under a single US authority, which exclusively manages incidents of abuse even though the referral may come from the German civil sector. As a result, it is possible to obtain more complete data than would usually be possible where there are competing jurisdictions and multiple agencies from which a family could receive services, such as county or state child protective services in addition to or instead of the US military. 


\section{Data}

The data for this research were obtained from a review of minutes of 181 case presentations of suspected cases to case review committees of child emotional abuse in 15 separate Army communities in Germany in 1997-1998. Minutes were reviewed because it was impractical to review case records at multiple locations in Germany. The data were consolidated into one group for this analysis, and will subsequently be referred to as the Army community. Incidents were coded as one of four types: primary emotional abuse (emotional abuse without another form of child maltreatment), witnessing spouse abuse, emotional abuse that occurred in conjunction with child physical abuse, and emotional abuse that occurred in conjunction with child neglect. Primary emotional abuse was defined as emotional abuse not in conjunction with any other type of abuse. Cases were examined for incidents that involved only a single child (62 incidents), and those that involved more than one child (50 incidents).

Two social workers with a high degree of familiarity with the FAP (a total of over 40 years of combined experience) reviewed and coded all case minutes for data on both the child victim and the adult offender, the latter in cases of spouse abuse witnessed by children. Data coded for the child were: age, sex, severity of the emotional abuse incident, degree of involvement of the child in the incident, response of the child to the incident, prior history of abuse, whether an assessment of the child had been noted in the case review minutes, stresses involved in the incident, and recommended interventions. Data recorded for the offenders were: age, sex, the relationship to the child, and prior history of the abuser in a FAP case.

The descriptions of the child abuse incidents provided in the minutes were coded as mild, moderate, or severe. Mild primary emotional child abuse consisted of single incidents or a small number of instances of a parent swearing, yelling at the child, or calling the child dumb or stupid. Moderate primary emotional abuse was a pattern of berating or yelling at the child. Severe primary emotional abuse was telling the child that he/she was hated, wishing that he or she had never been born, constant berating, or the threat of abandonment. Physical spouse abuse incidents that the child witnessed or was involved in were also coded as mild, moderate, or severe based on the severity of the spouse abuse incident. Examples of mild spouse abuse were pushing, shoving, or grabbing. Moderate incidents were single or several hits or slaps. Severe spouse abuse was grabbing by the throat, blows to the head, falling with injury to the head, multiple injuries, threatening or using a knife or gun, or an extended episode of abuse. The only items that required the rater to make a judgment were the severity of abuse ratings. The raters examined their coding for errors and disagreements in ratings. Disagreements were found in no more than 10 cases, and were easily resolved by discussion and re-reviewing the minutes.

\section{Results}

A total of 181 children were involved in emotional abuse incidents during this 2 -year period (Table 1). The largest number of cases was for children witnessing spouse abuse, $51 \%$ 
Table 1

Number and percentage of substantiated and unsubstantiated emotional abuse cases

\begin{tabular}{llllll}
\hline Type of emotional maltreatment & \multicolumn{2}{c}{ Substantiated cases } & & \multicolumn{2}{c}{ Unsubstantiated cases } \\
\cline { 2 - 3 } \cline { 5 - 6 } & Number & $\begin{array}{l}\text { Percent of all } \\
\text { substantiated cases }\end{array}$ & & Number & $\begin{array}{l}\text { Percent of all } \\
\text { unsubstantiated cases }\end{array}$ \\
\hline Primary $(n=59)$ & 32 & $(26 \%)$ & & & \\
Witnessing spouse abuse $(n=92)$ & 75 & & $(60 \%)$ & 17 & $(48 \%)$ \\
With child abuse $(n=20)$ & 13 & $(10 \%)$ & 7 & $(30 \%)$ \\
With child neglect $(n=10)$ & 5 & $(4 \%)$ & 5 & $(9 \%)$ \\
Total $(n=181)$ & 125 & $(100 \%)$ & & 56 & $(100 \%)$ \\
\hline
\end{tabular}

of all cases $(n=92)$. The second largest number were of primary emotional abuse, $32 \%(n=$ 59). These two categories accounted for more than $83 \%$ of all cases. Emotional abuse occurring in conjunction with child abuse accounted for $11 \%(n=20)$, while emotional abuse in conjunction with child neglect occurred in $6 \%$ of all cases $(n=10)$.

\section{Substantiation rate}

There were 125 substantiated and 56 unsubstantiated cases. The differences in substantiation by subtype of emotional abuse were statistically significant, $\chi^{2}(3, n=181)=$ $14.61, p=.002$. The largest number of substantiated cases $(n=75)$ was found in witnessing spouse abuse, more than twice that of the nearest other category, primary emotional abuse. The majority of incidents were substantiated for witnessing spouse abuse (82\%), primary emotional abuse (54\%), and emotional abuse occurring in conjunction with child physical abuse (69\%). The number of substantiated and unsubstantiated cases was equal for emotional abuse in conjunction with child neglect. Witnessing spouse abuse was substantiated significantly more often than primary emotional abuse, $\chi^{2}(1, n=151)=$ $12.96, p<.001$ (82\% vs. 54\%, respectively). Witnessing spouse abuse was also substantiated significantly more often than emotional abuse in conjunction with child neglect, $\chi^{2}(1$, $n=102)=5.30, p=.02(82 \%$ vs. $50 \%)$. The other comparisons between subtypes of abuse were not significantly different.

Age and sex

The ages of the children in substantiated incidents ranged from less than 1 year to age 17 . The mean ages of the children in substantiated cases ( 6.6 years, $s d=4.7, n=125$ ) were not significantly different from the unsubstantiated cases $(6.4$ years, $s d=4.7, n=49)$. The difference in mean age between girls (7.2 years, $s d=5.0, n=78)$ and boys (6.2 years, $s d=$ $4.4, n=72$ ) was also not statistically significant.

\section{Severity}

Seventy-five percent of the 125 substantiated cases were rated as either moderate or severe emotional abuse (Table 2). The greater the severity of the case, the more likely it was to be 
Table 2

Number of cases and percentage of case substantiation by severity of emotional abuse

\begin{tabular}{lccccc}
\hline Severity of emotional abuse & \multicolumn{2}{c}{ Substantiated cases } & & \multicolumn{2}{c}{ Unsubstantiated cases } \\
\cline { 2 - 3 } \cline { 5 - 6 } & Number & $\begin{array}{l}\text { Percent of all } \\
\text { substantiated cases }\end{array}$ & & Number & $\begin{array}{l}\text { Percent of all } \\
\text { unsubstantiated cases }\end{array}$ \\
\hline Mild $(n=77)$ & 31 & $(25 \%)$ & & & $(82 \%)$ \\
Moderate $(n=54)$ & 46 & $(37 \%)$ & 8 & $(14 \%)$ \\
Severe $(n=50)$ & 48 & $(38 \%)$ & & 2 & $(3.5 \%)$ \\
Total $(n=181)$ & 125 & $(100 \%)$ & 56 & $(100 \%)$
\end{tabular}

substantiated, $\chi^{2}(2, n=181)=53.45, p<.0001$. Ninety-six percent of all severe incidents and $85 \%$ of all moderate cases were substantiated, compared to $40 \%$ of all mild incidents. The same pattern of substantiation was seen in all four types of emotional abuse. For primary emotional abuse cases, $86 \%(n=18)$ of the moderate and $100 \%$ of the severe $(n=5)$ were substantiated (Table 3$)$. (Chi-square could not be computed because there were no unsubstantiated severe cases.) For cases of witnessing spouse abuse, $80 \%$ of the moderate $(n=20)$ and $95 \%$ of the severe $(n=36)$ cases were substantiated (Table 4$), \chi^{2}(2, n=$ $92)=9.38, p=.009$. For emotional abuse cases that occurred in conjunction with child abuse, $100 \%$ of the moderate $(n=7)$ and the severe $(n=9)$ were substantiated; for emotional abuse in conjunction with child neglect, 2 out 3 moderate cases and one severe case were substantiated.

\section{Clinical assessment of victim}

We examined the case minutes to determine if a clinical assessment of the child victim had been noted in the minutes. Because the minutes are a very limited summary, it was not possible to ascertain in every case if an actual clinical assessment of the child had or had not taken place. It may be that more assessments were actually performed, but we counted only those which were specifically mentioned in the case minutes. These figures are probably a conservative estimate of the number of clinical assessments actually performed. A clinical assessment (any kind of clinical assessment) of a child victim was specifically noted in 50\% (91 of 181) of all cases, substantiated and unsubstantiated. Whether an assessment had been

Table 3

Cases of primary emotional abuse by severity and percentage substantiated

\begin{tabular}{|c|c|c|c|c|}
\hline \multirow[t]{2}{*}{ Severity of emotional abuse } & \multicolumn{2}{|c|}{ Substantiated cases } & \multicolumn{2}{|c|}{ Unsubstantiated cases } \\
\hline & Number & $\begin{array}{l}\text { Percent of all } \\
\text { substantiated cases }\end{array}$ & Number & $\begin{array}{l}\text { Percent of all } \\
\text { unsubstantiated cases }\end{array}$ \\
\hline Mild $(n=33)$ & 9 & $(28 \%)$ & 24 & $(89 \%)$ \\
\hline Moderate $(n=21)$ & 18 & $(56 \%)$ & 3 & $(11 \%)$ \\
\hline Severe $(n=5)$ & 5 & $(16 \%)$ & 0 & $(0 \%)$ \\
\hline Total $(n=59)$ & 32 & $(100 \%)$ & 27 & $(100 \%)$ \\
\hline
\end{tabular}


Table 4

Cases of emotional abuse from witnessing spouse abuse by severity and percentage substantiated

\begin{tabular}{|c|c|c|c|c|}
\hline \multirow[t]{2}{*}{ Severity of emotional abuse } & \multicolumn{2}{|c|}{ Substantiated cases } & \multicolumn{2}{|c|}{ Unsubstantiated cases } \\
\hline & Number & $\begin{array}{l}\text { Percent of all } \\
\text { substantiated cases }\end{array}$ & Number & $\begin{array}{l}\text { Percent of all } \\
\text { unsubstantiated cases }\end{array}$ \\
\hline Mild $(n=29)$ & 19 & $(25 \%)$ & 10 & $(59 \%)$ \\
\hline Moderate $(n=25)$ & 20 & $(26 \%)$ & 5 & $(29 \%)$ \\
\hline Severe $(n=38)$ & 36 & $(48 \%)$ & 2 & $(12 \%)$ \\
\hline Total $(n=92)$ & 75 & $(100 \%)$ & 17 & $(100 \%)$ \\
\hline
\end{tabular}

noted did not differ between substantiated (51\%) cases and unsubstantiated cases (49\%). For all cases, substantiated and unsubstantiated, there was a significant difference in whether an assessment had been noted for children younger than 3 years (9\%) compared to children 3 years of age $(91 \%), \chi^{2}(d f=1, n=163)=18.12, p<.0001$. For children 3 years and older, assessments were noted in $64 \%$ of substantiated cases and $62 \%$ of unsubstantiated cases, but this difference was not statistically significant.

We also examined whether an assessment of the child was noted in the minutes in relation to the severity of the emotional abuse incident for all cases, for primary emotional abuse, and for witnessing spouse abuse. (There were not enough cases of child emotional abuse in conjunction with child abuse or child neglect to examine trends.) There was no apparent trend in whether an assessment was noted and the severity of the case. Assessments were noted in $49 \%$ of all mild cases, $50 \%$ of moderate cases, and $52 \%$ of severe cases. For primary emotional abuse, there was no overall difference in whether an assessment was performed and substantiation by severity for all cases (substantiated and unsubstantiated). The difference in severity by assessment was statistically significant for substantiated cases only, $\chi^{2}$ $(d f=2, n=32)=6.73, p<.05$. An assessment was noted for $33 \%$ of mild cases (3 of 9 ), $83 \%$ of moderate cases ( 15 of 18 ), and $60 \%$ of severe cases ( 3 of 5 ). The same pattern was true for cases of children of 3 years or older, but the differences were not statistically significant.

The relationship between child assessment and case severity for children witnessing spouse abuse was significant, $\chi^{2}(d f=2, n=92)=7.57, p<.05$. Child assessments were noted in $34 \%(n=31)$ of all cases: $38 \%$ of mild cases $(n=11$ of 29$), 12 \%$ of moderate cases $(n=3$ of 25$)$, and $45 \%$ of severe cases $(n=17$ of 21$)$. When only substantiated cases were examined, the same pattern was found, $\chi^{2}(d f=2, n=75)=9.60, p<.01$. Assessments were noted in $53 \%$ of mild cases (10 of 19), $10 \%$ of moderate cases $\left(\chi^{2}\right.$ of 20$)$, and $47 \%$ of severe cases (17 of 36 ). For children 3 years of age and over in substantiated cases, the same pattern was found with slightly higher substantiation rates for all three categories of severity of the spouse abuse incidents, $\chi^{2}(d f=2, n=52)=7.24, p<.05$ : $67 \%$ of mild cases ( 8 of 12), $17 \%$ of moderate cases ( 2 of 12), and $57 \%$ of severe cases (16 of 28). This pattern shows a higher percentage of assessments performed for the mild and severe cases, but a relatively low percentage for the moderate cases. The reasons for this pattern are unclear, but it may be easier to judge mild and severe incidents, than to determine what is a moderate one. 


\section{Child involvement in spouse abuse incidents}

There were different levels of involvement of the children in the substantiated spouse abuse incidents: the child was in the home when the incident occurred, saw the incident, was held by one of the parents, or was physically involved (such as tried to stop the incident). A total of 85 types of involvement were reported. In 44 cases $(52 \%)$, the child saw the incident, and in $20(24 \%)$ he or she tried to stop it. In $11(13 \%)$ cases, children were physically involved, $6(7 \%)$ were held, and $4(5 \%)$ were in the home.

\section{Treatment plans}

The interventions recommended in the treatment plans were also recorded in the minutes. For substantiated emotional abuse incidents there were an average of three interventions recommended per incident. The most frequently recommended interventions in rank order were: group treatment (such as anger management, domestic violence containment programs, parents of attention deficit hyperactivity disorder, and children's support group); parenting classes/involvement with new parent support group; marriage and family counseling; and individual treatment for the parent or child.

\section{Prior history of abuse and family comparisons}

Cases with a prior history of abuse, 66 out of 80 (82.5\%), were significantly more likely to be substantiated compared to those without such a prior history, 39 out of $67(58.2 \%), \chi^{2}$ $(d f=1, n=147)=10.54, p<.001$. Families in which there was known prior child abuse (39 families out of 50) were 1.49 times (95\% confidence limits $=1.25-2.02$ ) more likely to have cases substantiated than families without such a history (22 out of 42), $\chi^{2}$ $(d f=1, n=92)=6.71, p=.01$. Families in which there was more than one child who witnessed a spouse abuse incident were 1.55 times $(95 \%$ confidence limits $=1.18-2.04)$ more likely to be substantiated compared to families in which there was only one child, $\chi^{2}$ $(d f=1, n=112)=9.72, p<.001$. In 40 out of $50(80 \%)$ families, those families having more than one child were more likely to have a substantiated case, compared to 32 children out of $62(52 \%)$ families with only one child.

\section{Offenders}

Data were obtained on 119 offenders. All offenders were between the ages of 18 and 51 . Eighty-two percent were parents; $18 \%$ were step or adoptive parents. Ninety-two percent were married; $8 \%$ were divorced or separated. Male offenders $(n=79)$ outnumbered females $(n=40)$ in all age groups except 47-51, where there was only one offender, a female.

\section{Discussion}

In this study, the most frequently substantiated category of child emotional abuse was that of children who witnessed spouse abuse, more than twice that of primary emotional abuse. 
It may be that this form of child emotional maltreatment is substantiated at a higher rate than the other subtypes because it is easier to identify than the others. The number of substantiated cases of child emotional abuse in conjunction with child physical abuse or neglect was small, less than $15 \%$ of the total number of cases. The more severe the incident the more likely it was to be substantiated, but there was no relationship between whether a clinical assessment was done and either case substantiation or case severity. Not all children exposed to spouse abuse respond the same way (Graham-Bermann \& Hughes, 1998; Margolin \& Gordis, 2000). As a result, it is important to provide some clinical assessment and report that assessment for records (even if the results are negative). Such information should always be available for treatment planning.

It is noteworthy that the vast majority of the emotional abuse cases identified and substantiated by the Army CRCs were not in combination with other types of child abuse. This is contrary to reports in which emotional abuse was present in most cases of physical abuse and neglect (Claussen \& Crittenden, 1991; Crittenden, Claussen, \& Sugarman, 1994). Hart and Brassard (1991) noted that populations in which pure forms of psychological maltreatment exist appear more likely to be found outside of the populations processed by the usual child protection jurisdictions. While child physical abuse and neglect do occur in the Army community, it is generally believed by Army Family Advocacy Program personnel that much of the substantiated physical abuse and neglect does not usually reach the level of severity of cases seen in communities served by civilian child protective services. As a result, it is less likely that emotional abuse would be a concomitant of cases of child physical abuse and neglect in this population. These findings suggest that, in these CRCs in the Army, emotional abuse is generally viewed as a discrete type of maltreatment, particularly for children who witness spouse abuse, and not one that occurs more frequently with child physical abuse or neglect. An advantage of seeing emotional abuse as a single entity may be to allow focus on a relationship or situation (such as spouse abuse) that is potentially harmful to a child that might not be seen if the emphasis were solely on the more severe and obvious forms of child abuse and neglect. On the other hand, recognizing the emotionally abusive aspects of child physical abuse and neglect could allow an expanded treatment plan, one that could include treatment of the emotionally abusive behavior to strengthen the relationship of the caregiver to the child, in addition to the focus on the physical abuse and neglect. Additionally, CRCs may be addressing co-existing issues of emotional maltreatment in the treatment plan for the physical abuse or neglect without identifying it as a separate maltreatment issue. Clinicians and CRCs should remember that each type of maltreatment should be identified separately, and incorporated within a treatment plan that includes all components of maltreatment, including the maltreatment of spouses.

Given that definition, substantiation and intervention in emotional abuse cases are difficult, a community-wide educational and preventive approach may be more effective in reducing child emotional abuse than bringing parents before legal and social authorities. The Army provides parents with educational and home visitation programs that may alert them to the harm of chronic patterns of parental behavior that could be injurious to children. Another avenue toward protection is to attempt to change parental attributes and the relationship between the parent and the child. While this approach may require more time, it would also allow for a full assessment and a trial of intervention. The intervention 
recommendations in the substantiated incidents in this sample appear to follow this broader approach.

It is important to continue to explore and develop models of how and why emotional abuse might affect the behavior and development of children. Attempts to decrease the effects of the emotional maltreatment of children must cope with a number of difficult theoretical and practical issues. Graham-Bermann and Hughes (1998) have called for an ecological model of how children are affected by domestic violence, models that include factors outside the family such as the availability of medical and legal services. The US military may provide a unique opportunity in which to test such models since many of these ecological factors are contained in the military environment.

Regardless of definitional issues, theoretical justifications, and the state of research, child protection services are finding more and more cases of emotional abuse in children (GrahamBermann \& Hughes, 1998). In addition to the other questions raised in this paper, a study of community values and issues in which there is both consensus and disagreement on definitions, standards, and criteria for the emotional abuse of children are also worthwhile research issues to pursue as this field of child protection develops. For example, some jurisdictions are willing to investigate and substantiate child emotional abuse of children who witness spouse abuse. In some cases, such substantiation is closely related to court procedures against the spouse abuse perpetrator, while in others it may be based only on child protective services decisions. There are important implications to a policy of automatically substantiating child emotional abuse in cases of witnessing spouse abuse. Among these are the volume of cases that can be handled by a county or state, the need for additional funds to support investigation and adjudication, issues of due process for the perpetrator, and the labeling of a child as an abuse case. In this study, these questions were beyond the scope of the study, but must be considered by any jurisdiction that contemplates the impact of children witnessing spousal abuse.

There are limitations to this study. The cases reviewed are not necessarily representative of the entire Army Family Advocacy Program. Case substantiation varies according to the composition of the CRC at each medical treatment facility, and changes in the interpretations of standards and definitions. Secondly, the Army FAP reviews both child abuse and neglect cases and spouse abuse cases. As a result, spouse abuse incidents in families that have children are more likely to raise the question of whether a child witnessed or was involved in the spouse abuse incident. This close examination of spouse abuse is apt to produce more cases of child emotional abuse than would be identified by civilian child protective services.

\section{Acknowledgements}

The authors wish to acknowledge Teege Culp and SGT Frank Miller for their assistance with data collection and analysis.

\section{References}

APSAC (1995). Guidelines for psychosocial evaluation of suspected psychological maltreatment in children and adolescents. Chicago, IL: American Professional Society on the Abuse of Children. 
Army Regulation 608-18. (1995). Headquarters, Department of the Army, Washington, DC.

Brassard, M. R., Hart, S. N., \& Hardy, D. (1993). The psychological maltreatment rating scales. Child Abuse \& Neglect, 17, 715-729.

Briere, J., \& Runtz, M. (1990). Differential adult symptomatology associated with three types of child abuse histories. Child Abuse \& Neglect, 14, 357-364.

Broadhurst, D. D. (1984). The educator's role in the prevention and treatment of child abuse and neglect. Washington, DC: National Center on Child Abuse and Neglect, US Department of Health and Human Services.

Claussen, A. H., \& Crittenden, P. M. (1991). Physical and psychological maltreatment: relations among types of maltreatment. Child Abuse \& Neglect, 15, 5-18.

Crittenden, P. M., Claussen, A. H., \& Sugarman, D. B. (1994). Physical and psychological maltreatment in middle childhood and adolescence. Development and Psychopathology, 6, 145-164.

Fantuzzo, J., Boruch, R., Beriama, A., Atkins, M., \& Marcus, S. (1997). Domestic violence and children: prevalence and risk in five major cities. Journal of the American Academy of Child and Adolescent Psychiatry, $36,116-122$.

Fergusson, D. M., \& Horwood, L. J. (1998). Exposure to interparental violence in childhood and psychosocial adjustment in young adulthood. Child Abuse \& Neglect, 22, 339-357.

Garbarino, J., Guttman, E., \& Seeley, J. (1986). The psychologically battered child: strategies for identification, assessment, and intervention. San Francisco, CA: Jossey-Bass.

Garbarino, J., \& Vondra, J. (1987). Psychological maltreatment: issues and perspectives. In M. R. Brassard, R. Germain, \& S. N. Hart (Eds.), Psychological maltreatment of children and youth (pp. 22-24). New York: Pergamon Press.

Garrison, E. G. (1987). Psychological maltreatment of children. American Psychologist, 42, 157-159.

Glaser, K., \& Prior, V. (1997). Is the term child protection applicable to emotional abuse? Child Abuse Review, 6, 315-329.

Gough, D. (1996). Defining the problem. Child Abuse \& Neglect, 20, 993-1002.

Graham-Bermann, S. A., \& Hughes, H. M. (1998). The impact of domestic violence and emotional abuse on children: the intersection of research, theory, and clinical intervention. Journal of Emotional Abuse, 1, 1-21.

Gross, A. B., \& Keller, H. R. (1992). Long-term consequences of childhood physical and psychological maltreatment. Aggressive Behavior, 18, 171-185.

Grych, J. R., \& Fincham, F. D. (1990). Marital conflict and children's adjustment: a cognitive-contextual framework. Psychological Bulletin, 2, 267-290.

Hart, S. N., Binggeli, N. J., \& Brassard, M. R. (1998). Evidence for the effects of psychological maltreatment. Journal of Emotional Abuse, 1, 27-58.

Hart, S. N., \& Brassard, M. R. (1987). A major threat to children's mental health. Psychological maltreatment. American Psychologist, 42, 160-165.

Hart, S. N., \& Brassard, M. R. (1991). Psychological maltreatment: progress achieved. Development and Psychopathology, 3, 61-70.

Hart, S. N., Germain, R., \& Brassard, M. R. (1987). The challenge: to better understand and combat the psychological maltreatment of children and youth. In M. R. Brassard, R. Germain, \& S. N. Hart (Eds.), Psychological maltreatment of children and youth (pp. 3-24). New York: Pergamon Press.

Henning, K., Leitenberg, H., Coffey, P., Bennett, T., \& Jankowski, M. K. (1997). Long-term adjustment to witnessing interparental physical conflict during childhood. Child Abuse \& Neglect, 21, 501-515.

Hughes, H. M. (1988). Psychological and behavioral correlates of family violence in child witnesses and victims. American Journal of Orthopsychiatry, 58, 77-90.

Jaffe, P., Wolfe, D., Wilson, S., \& Zak, L. (1986). Similarities in behavioral and social maladjustment among child victims and witnesses to family violence. American Journal of Orthopsychiatry, 56, 142-146.

Kaplan, S. J., Pelcovitz, D., \& Labruna, V. (1999). Child and adolescent abuse and neglect research: a review of the past 10 years. Part I: physical and emotional abuse and neglect. Journal of the American Academy of Child and Adolescent Psychiatry, 38, 1214-1222. 
Kent, A., \& Waller, G. (1998). The impact of childhood emotional abuse: an extension of the child abuse and trauma scale. Child Abuse \& Neglect, 22, 393-399.

Kolbo, J. R. (1996). Risk and resilience among children exposed to family violence. Violence and Victims, 11, $113-128$.

Kolbo, J. R., Blakely, E. H., \& Engleman, D. (1996). Children who witness domestic violence: a review of the empirical literature. Journal of Interpersonal Violence, 11, 281-293.

Lehmann, P. (2000). Posttraumatic stress disorder (PTSD) and child witnesses to mother-assault: a summary and review. Children and Youth Services Review, 22, 275-306.

Margolin, G., \& Gordis, E. B. (2000). The effects of family and community violence on children. Annual Review of Psychology, 51, 445-479.

Maslow, A. H. (1970). A theory of human motivation. New York: Harper \& Row.

McCarroll, J. E., Thayer, L. E., Newby, J. H., Ursano, R. J., Norwood, A. E., \& Fullerton, C. S. (1999). Trends in child maltreatment in the US Army, 1975-1997. Child Abuse \& Neglect, 23, 855-861.

McGee, R. A., \& Wolfe, D. A. (1991). Psychological maltreatment: toward an operational definition. Development and Psychopathology, 3, 3-18.

Mullen, P. E., Martin, J. L., Anderson, J. C., Romans, S. E., \& Herbison, G. P. (1996). The longterm impact of the physical, emotional, and sexual abuse of children: a community study. Child Abuse \& Neglect, 20, 7-21.

Navarre, E. (1987). Psychological maltreatment: The core component of child abuse. In M. R. Brassard, R. Germain, \& S. N. Hart (Eds.), Psychological maltreatment of children and youth (pp. 45-48). New York: Pergamon Press.

O'Keefe, M. (1998). Factors mediating the link between witnessing interparental violence and dating violence. Journal of Family Violence, 13, 39-57.

Rosenberg, M. S. (1987). New directions for research on the psychological maltreatment of children. American Psychologist, 42, 166-171.

Sanders, B., \& Becker-Lausen, E. (1995). The measurement of psychological maltreatment: early data on the child abuse and trauma scale. Child Abuse \& Neglect, 19, 315-323.

Sedlak, A. J., \& Broadhurst, D. D. (1996). Third national incidence study of child abuse and neglect. US Department of Health and Human Services, Administration for Children and Families, Administration on Children, Youth and Families, National Center on Child Abuse and Neglect.

Somer, E., \& Braunstein, A. (1999). Are children exposed to interparental violence being psychologically maltreated? Aggression and Violent Behavior, 4, 449-456.

Thompson, A. E., \& Kaplan, C. A. (1996). Childhood emotional abuse. British Journal of Psychiatry, 168, $143-148$.

US Department of Health and Human Services. Administration on Children, Youth and Families (1999). Child maltreatment 1997: reports from the states to the national child abuse and neglect data system. Washington, DC: US Government Printing Office.

US Department of Health and Human Services. Office of Human Development Services, Administration on Children, Youth and Families, Children's Bureau, National Center on Child Abuse and Neglect. (1981). Study findings: national study of the incidence and severity of child abuse and neglect. DHHS Publication (OHDS) 81-30325, September 1981. Washington, DC.

US Department of Health and Human Services. Office of Human Development Services, Administration on Children, Youth and Families, Children's Bureau, National Center on Child Abuse and Neglect. (1988). Report on data processing and analysis. Study of national incidence and prevalence of child abuse and neglect. Clearinghouse on Child Abuse and Neglect Information (DHHS), Washington, DC.

Wald, M. (1961). Protective services and emotional neglect. Denver, CO: American Humane Association. 2000.

\section{RÉSUMÉ}

Objectif: Les signalements pour mauvais traitements psychologiques ont énormément augmenté pendant les dix dernières années. L'objectif de cette recherche fut de déterminer les types de mauvais 
traitements psychologiques qui furent prouvés à l'intérieur d'une communauté de familles de l'Armée américaine résidant temporairement en Allemagne. Une telle description pouvant aider à mieux comprendre comment une juridiction définit les mauvais traitements psychologiques dans la pratique quodienne.

Méthode: Les données ont été obtenues à partir des procès-verbaux des comités d'évaluation des cas (CRCs) et ont concerné 181 enfants victimes de violence psychologique en 1997 et 1998. Nous avons déterminé le type, le nombre et la gravité des incidents, le taux de preuves et les situations auxquelles les enfants ont été exposés.

Résultats: Le type d'incident le plus souvent prouvé consista le plus souvent à être témoin de violence domestique, dans $60 \%$ des cas. Des violences psychologiques furent trouvées dans $26 \%$ des cas comme facteur principal et dans $14 \%$ des cas associées à des mauvais traitements physiques.Plus le cas était grave plus il était susceptible d'être prouvé.

Conclusions: C'est comme type isolé de violence que les mauvais traitements psychologiques furent prouvés plus qu'en association avec d'autres formes . Considérer la violence psychologique comme une entité isolée peut permettre aux cliniciens de se centrer sur une relation ou une situation (tout comme les abus sur l'épouse) qui peut être dommageable pour l'enfant. Toutefois, le fait de reconnaître des aspects de violence psychologique dans les mauvais traitements physiques et la négligence pourrait permettre de planifier un traitement plus étendu des comportements produisant des abus psychologiques. La relation de l'intervenant avec l'enfant pourrait en être renforcée, ceci s'ajoutant à une attention aux mauvais traitements physiques et à la négligence.

\section{RESUMEN}

Objetivo: A lo largo de la última década han aumentado sustancialmente las notificaciones de maltrato emocional. El objetivo de este estudio es determinar los tipos de maltrato emocional confirmados en un grupo de familias pertenecientes al ejército americano que residen temporalmente en Alemania. Esta descripción puede ayudar a mejorar la comprensión de cómo se define el maltrato emocional en la práctica cotidiana en el ámbito jurídico.

Método: Los datos fueron obtenidos a partir de la revisión de las actas de los comités de seguimiento de caso, correspondientes a 181 casos de maltrato emocional durante los años 1997 y 1998. Se determinó el tipo, número y severidad de los incidentes, la tasa de confirmación y las situaciones a las que fueron expuestos los niños.

Resultados: El tipo de incidente confirmado de manera más frecuente fue el ser testigo de violencia familiar (60\%). En un $26 \%$ de los casos se observó el maltrato emocional como situación primaria, mientras que en un $14 \%$ de los casos el maltrato emocional se presentó en conjunción con el maltrato físico infantil. En la medida en que el caso es más severo, se da una tasa más elevada de confirmación. Conclusiones: El maltrato emocional fue confirmado de manera más frecuente cuando se presenta como tipo único que en combinación con otras formas de maltrato. La observación del maltrato emocional como una entidad única puede hacer que los clínicos se focalicen en la relación o la situación (como el maltrato a la pareja) que es potencialmente dañina para el niño. Sin embargo, el reconocimiento de aspectos de maltrato emocional en situaciones de maltrato físico o negligencia física puede hacer que el plan de tratamiento de amplíe para incluir el fortalecimiento de la relación del cuidador/a y el niño/a, además del tratamiento correspondiente al maltrato o abandono emocional. 